\title{
Analysis of photosynthetic and water-use efficiency of piper aduncun in a degraded area from gaseous exchange
}

\author{
Rebeca P Guimarães, Vinícius P Duarte, Breno R Santos, Thiago C de Souza \\ From 5th Congress of the Brazilian Biotechnology Society (SBBIOTEC) \\ Florianópolis, Brazil. 10-14 November 2013
}

\section{Background}

Plants are able to survive in a distinctive environment from its usual one, especially due to morphological or physiological changes, thus a good ability of acclimatization and phenotypic plasticity is present [1]. Light and water availability are decisive factors in a plant's survival, the occurrence of those is irregular, because luminosity is broadly available on the edges and large clearingsaccording to the criteria proposed by Souza, et al.[3] and scarce inside woods [2] and water availability depends on local pluviosity. Considering this, studies relating photosynthesis and water-use efficiency to phenotypic plasticity are major to the discovery of species capable of tolerating degraded environments with diverse luminous and pluvious intensity, thus, contributing to the enhancement of them. Based on the given information, this study aims to look into the behavior of these variables in Piper aduncum through gas exchange in distinctive spots of a gully.

\section{Methods}

The study was performed at a rural property in AlfenasMG between the months of January-April 2013. The local vegetation found on the region is semi-deciduous with little native species.

The gas exchange parameter was measured through a portable photosynthesis gas exchange system (IRGA, Model LI-6400XT, Li-Cor, Lincoln, Nebraska, USA). All measures were made through the morning between $8 \mathrm{AM}$ and 11AM, on a fully expanded leaf area and with due phytosanitary measures.

The evaluated parameters were: foliar photosynthetic rate (A) and the water-use efficiency (A/gs). The measures were taken on a foliar area of $6 \mathrm{~cm}^{2}$, the chamber's air flow had a $\mathrm{CO}_{2}$ concentration of $380 \mu \mathrm{mol} \mathrm{mol}{ }^{-1}$. The air was collected through outside of the gully and then transported inside a protected container and then pumped to the chamber. A photosynthetic photon flux density (PFFD) of $800 \mu \mathrm{mol} . \mathrm{m}^{-2} . \mathrm{s}^{-1} 1$ was used from an artificial light source (LI-6400-02B RedBlue LED, Li-Cor). The temperature was kept at $28^{\circ} \mathrm{C}$. The experimental designs were entirely randomized with 3 treatments (area of the edge, slope and the gully's bottom) with twelve repetitions. Averages and standart errors were done for data analisys.

\section{Results and conclusions}

In this context, the study has shown that the photosynthetic rate was bigger on the edges of the gully $(11,37$ $\left.\mu \mathrm{mol} . \mathrm{m}^{-2} \cdot \mathrm{s}^{-1} \pm 1,06\right)$ and the water-use efficiency on the edges and the slope were equal. The difference between the treatments results from the slope and the gully's bottom can be explained, due to the fact that when the data was collected, sunlight rays passed through the canopy and despite that usually happening in a short amount of time, it can contribute actively to the photosynthetic photon flux, and thus, increasing photosynthetic activity [4]. The gully bottom showed lower water-use efficiency, therefore photosynthesis was small in relation to stomatal conductance.

Results lead to conclude that Piper aduncumdemonstrates behavior prone to acclimatization and consequently of phenotypic plasticity when exposed to diverse luminousand water intensity from different spots of a degraded area.

Published: 1 October 2014

Universidade Federal de Alfenas, Alfenas, Brazil 


\section{References}

1. Schlichting CD, Smith H: Phenotypic plasticity: linking molecular mechanisms with evolutionary outcomes. Evolutionary Ecology 2002, 16:189-211.

2. Martins SV, Rodrigues RR: Gap-phase regeneration in a semideciduous mesophytic Forest, south-eastern Brazil. Plant Ecology 2002, 163(12):51-62.

3. Souza GM, et al: Diurnal and seasonal carbon balance of four tropical tree species differing in successional status. Brazilian Journal of Biology 2008, 68(4):781-793.

4. Pezzopane JE, et al: Radiação luminosa e fotossíntese em quatro espécies lenhosas no interior de um fragmento de floresta secundária semidecidual. Floresta e Ambiente 2003, 10:48-57.

doi:10.1186/1753-6561-8-S4-P129

Cite this article as: Guimarães et al:: Analysis of photosynthetic and

water-use efficiency of piper aduncun in a degraded area from gaseous exchange. BMC Proceedings 2014 8(Suppl 4):P129.

\section{Submit your next manuscript to BioMed Central} and take full advantage of:

- Convenient online submission

- Thorough peer review

- No space constraints or color figure charges

- Immediate publication on acceptance

- Inclusion in PubMed, CAS, Scopus and Google Scholar

- Research which is freely available for redistribution

Submit your manuscript at www.biomedcentral.com/submit 